\title{
EXAMINING GENDER-BASED INCLUSIVE EDUCATIONAL INTERVENTIONS IN THE KADJEBI DISTRICT, GHANA
}

\author{
${ }^{* 1}$ Agbenyo, F. \& Sarkpoh², F. \\ ${ }^{1}$ Department of Planning, Faculty of Planning and Land management, P.O. Box UPW 3, University for Development Studies. Wa Campus. Upper \\ West Region. Emails: fagbenyo@uds.edu.gh and afausters@yahoo.com \\ ${ }^{2}$ Department of Governance and Development Management, Faculty of Planning and Land management, P.O. Box UPW 3, University for \\ Development Studies.Wa Campus. Upper West Region.Email: faustinasarkpoh@ymail.com
}

\begin{abstract}
Reports from various evaluations of the Millennium Development Goal (MDG) 2 indicate that even though a great deal of success had been chalked, a lot more was yet to be attained. In 2013, just two years to 2015, which marked the end of the MDG target year, the Kadjebi District was declared a deprived district in terms of education. The paper employed the lenses of social exclusion/inclusion and theory of change. It examined the extent of gender participation in and achievement of other results of education development interventions, now derived from the Sustainable Development Goal (SGD) 4. Basically, the paper used quantitative data from a secondary source after the Kadjebi District was selected from a group of six deprived districts, using a simple random sampling technique. It emerged that Kadjebi is faring well in terms of interventions targeting access to JHS and SHS education by gender but not much progress in the area of indicators measuring quality of education. It is recommended that all stakeholders, particularly, NGOs that were undertaking the interventions, collaborate to diagnose the factors militating against achievement of the quality objective of their interventions and dwell on their respective competitive advantage to create the necessary synergies to be able to tackle these challenges head-on in the District.
\end{abstract}

Keywords: Education Intervention, Gender, World Bank, Sustainable Development Goals, Ghana.

\section{Introduction}

Globally, issues of gender in development circles evolved from Women in Development (WID) since the mid-1960s, focusing on how lots of women could be bettered to enable them claim equality with their men counterparts. This was intended to engender their efficient and pivotal roles in all segments of societal development (March et al., 1999 reprinted 2005). The United Nations (UN) convened a number of world conferences that birthed the concept of WID in international and national development circles. UN Commission on the Status of Women (CSW) championed the Declaration to Eliminate
Discrimination against Women in 1965, with the first conference in Mexico, 1975, christened World Conference of the International Women's Year, which adopted the Declaration on the Equality of Women and their Contribution to Development and Peace, the institution of 1975 as International women's year, March 8 of every year as International Women's Day, the formulation of the World Action Plan for the implementation of the Mexico Declaration goals and declaration of 1975 to 1985 as the UN Decade of Women. In July 1980, the second World Conference on Women was held in 
Copenhagen, Denmark, where progress made towards the implementation of the goals set in the World Action Plan was assessed and the Convention on the Elimination of All Forms of Discrimination against Women by the UN member countries was signed. The third World Conference on Women held in Nairobi, Kenya in 1985 sealed the UN Decade for Women and established schedules for member states to remove laws that aided discrimination against women from their legislative frameworks. A decade after the UN Decade of Women, the Fourth World Conference on Women was held in Beijing, China, in 1995. Focal to that conference was the Declaration and Platform for Action targeted at the realisation of more equality and better opportunities for women as contained in the previous declarations (see Ameyibor, 2019).

WID was criticized that absolute concentration of development interventions on women and girls against men and boys would eventually lead to a reversal of the situation where instead of equality, there would be discrimination against and disadvantageous positions of men and boys relative to those of women and girls. As such, men in some households and even modern institutions resisted purely feminist approaches to development. The current literature, thus, has what is referred to as Gender and Development (GAD), which is focused on how the inequalities and inequities between women's and girls', on the one hand, and men's and boys' socially-assigned roles, responsibilities, relationships, entitlements and benefits, on the other, can be addressed for smooth societal development (March et al., 2005), culminating in a mix of WID and GAD with more affirmative actions being implemented. Thus, affirmative actions favour women more than men, as in almost all spheres of societal development globally, it remains factual that women and girls are more disadvantaged than their men and boys' counterparts (Ameyibor, 2019). In Ghana, a key global event that spurred concerns and actions for WID/GAD, was the Beijing Conference, where the then First Lady of Ghana chaired one of the sessions, with a high national media publicity. This gave more prominence to the $31^{\text {st }}$ December Women's Movement (DWM), the first quasi-non- governmental and political organization which among others "established day-care centres and nurseries [...]" (African Confidential, 1989;8). Following this pioneering work from the mid-1980s through the 1990s to the 2000s, the evolution of the concept of WID through GAD on the development scene in Ghana, several developmental entities, governmental and non-governmental, were established with several policy measures, programmes, projects and actions implemented with the view to eliminating/minimizing gender inequalities and inequities for a holistic, effective and efficient development.

The poor educational standards in the Kadjebi District of the Oti Region of Ghana, measured against the UN Millennium Development Goal 2: "Achieve universal primary education by 2015" (FAO, 2020), resulted in its eventual declaration as a deprived district in terms of education in 2013 by the Ghana Education Service and Ministry of Education (Boateng \& Ansah, 2014; Ansah, 2011). Following this, a number of educational interventions from both governmental and non-governmental organisations were initiated for improving education in the District. This included the World Bank/Bank of Ghana intervention christened Global Partnership Education Grant (GPEG), spanning 2013 to 2016. It targeted day-to-day running of schools with funds for teaching and learning materials, minor repairs on school buildings and teacher incentive packages. Later organisations and initiatives were guided by the UN Sustainable Development Goal (SDG) 4, "Ensure inclusive and equitable quality education and promote lifelong learning opportunities for all" (UNESCO-UIS, 2018; UNESCO, 2017; UNESCAP, 2015; UNDP, n.d.). These organisations include World Vision, Ghana and Action Aid, Ghana which focused their programmes on girl child education. While World Vision focuses on sponsorship of children including girls, Action Aid targeted school drop-outs, who are girls due to teenage pregnancy and integrating them back into the school system. Thus, figures presented in the results and discussion sections of this paper are jointly and incrementally generated from a constellation of programme interventions. 
The aim of the paper is, therefore, to examine gender disaggregated performance of educational interventions in the district, using various SDG indicators and theoretical lenses of social exclusion/inclusion and theory of change. The rest of the paper includes theoretical and conceptual frameworks, some empirical aspects on gender and education in Ghana, methodology, results and discussion, conclusions and policy prescriptions.

\section{Theoretical Lens: Inclusion/Exclusion and Theory of Change}

The paper made use of theory of inclusion/exclusion (Rawal, 2008; Burchardt, 2002; Muddiman, 1999a, b), useful in foregrounding the creation of space for the marginalised in terms of gender and the district to participate meaningfully in education. The theory of change (TOC) (Gertler et al., 2016; Rogers, 2014) was also used, which has helped in understanding the programme logic through which various interventions went to produce the results that form the basis of analysis in the paper. Exclusion is conceived of as:

\section{"If we assume that there is a set of core activities, which constitute participation in society, then an individual [or a group] is socially excluded in case two conditions are met: the individual is not participating for reasons beyond his/her control, and he/she would like to participate" (Agbenyo, 2019: 134; Burchardt et al., 2002).}

Areas of activity from which an individual or group of persons can be excluded include consumption, production, political engagement and the social aspects. Agbenyo (2019) argues that the social aspects are a constellation of areas including education and gender participation adding that access to information which can lead to enlightenment can also be considered as one area of exclusion as lack of information on opportunities to participate in education can result in exclusion. Agbenyo (2019) further elucidates that children of parents who have the means to educate them but not

Agbenyo et al., 2021: UDSIJD Vol 8(2) the required information on opportunities or its essence can still be excluded from mainstream education. For Muddiman (1999a; 1999b), social exclusion occurs with respect to lack of material resources, inadequate social participation, lack of cultural and educational capital, inadequate access to services and lack of power - the complexity of powerlessness. In Duffy (1995), social exclusion beside material means, encompasses the inability to effectively participate in economic, social, political and cultural life as well as alienation and distance from mainstream society.

The twin of social exclusion is social inclusion. Cameron (2006) posits that, social inclusion hinges on how to include or make a people part of the labour market, economy, society, culture and citizenship. Other areas are education, health and income groups (Slavin, 2010; Chapman, 2006; De la Brière \& Rawlings, 2006). As such, social inclusion is now contextualized to mean a policy process that is operationalized using programme and/or project interventions, in which individuals or group of persons are reintegrated into the mainstream functioning areas of society particularly education and gender participation.

The theory of change (TOC) focuses on the causal logic of how and why a particular programme, programme modality (rules or design innovation) reach its intended outcomes. Archibald et al., 2016; 3 ), defines TOC as "a theory of how and why an initiative works". Rogers (2014: 3) posits that TOC is "a building block for impact evaluations" and that it should be used in every impact evaluation investigation which Cornnell and Klen (2000) argue makes the results rigorous, timely and useful. TOC states that there is an undesirable state of affairs in a functioning area of society such as deplorable state of education including low gender participation as was the case prior to the interventions in Kadjebi. This justifies the injection of an intervention in various forms from different external agents. As a result of these interventions, the outcomes of interest in the form of educational indicators will leapfrog and put the District on the path of sustainable educational development. It is used to indicate the 
logical sequence of events leading to outcomes and eventually impacts. One critical aspect of detailing a TOC is the conditions and assumptions that must hold for the change to occur. In a TOC, the causal logic that drives the programme is clarified, with a map (results or impact chain model see Figure 1) (Gertler et al., 2016; Rogers, 2014; UNFPAUNICEF, 2013; Department of Social Development, 2012; Gertler et al., 2011; White, 2009), showing the logical causal pathway(s) of the interventions (Gertler et al., 2016; 2011).

The results/impact chain model which is used to pictorially represent TOC is a sequence of various implementation strategies with various assumptions and associated results and their indicators of success. The implementation strategies are various inputs expended, activities undertaken to produce the output(s) and eventually impacts (see Gertler et al., 2016; Rogers, 2014; UNFPA-UNICEF, 2013; Department of Social Development, 2012; White, 2009). Educational interventions come in the form of an assemblage of inputs of building materials, teaching and learning materials, labour/personnel and transportation equipment among others. These are used to undertake various intervention activities that produce results at various levels. Typifying TOC in the paper (see Figure 1), one can identify the problems of low gender participation emanating from high drop-out rates of girls due to teenage pregnancy, poor state of infrastructure, low pupil/student-teacher ratios, poor pupils and students' performance at the Basic Education Certificate Examination (BECE), and West African Schools Certificate Examinations (WASCE) and Senior High School Certificate Examination (SHSCE) respectively confronting the District. Specific strategies in educational development include educational infrastructural development, provision of teaching and learning materials, recruitment and retention of teachers and teenage mothers' return to school. These strategies are expected to produce the intended outputs (completed school buildings, increased school enrolment, increased number of teaching and learning materials (TLMs), increased number of teachers and increased number of teenage mothers that return to school) when assumptions/risks (proper planning of strategies, programmes and projects, proper implementation, timely release of resources and conducive policy environment) play out favourably. Indicators of success that go with the output level are number of school buildings completed, percentage increase in school enrolment, percentage increase in TLMs, percentage increase in number of teachers recruited and retained and percentage increase in number of teenage mothers that have returned to school. These outlined-outputs will result in planned outcomes that come in the form of improvement in school infrastructure, improved BECE, and WASCE and SHSCE results, improvement in the teaching and learning environment and improvement in gender participation in Junior and Senior High Schools given that outcome level assumptions/risks of students taking learning seriously, improvement in teacher retention as well as willingness and ability of teenage mothers to participate in the programme happen as held under the programme. Here, the outcome level indicators of success include percentage increase in infrastructure development, percentage increase in BECE and WASCE/SHSCE results, Pupil/Student-Teacher Ratio and Gender Parity Index. Finally, these outcomes will result in impacts (Improved standard of education, high completion rate, high rate of entry into tertiary institutions and gender equality/equity in education) when underlining assumptions and risk factors of active participation by all actors and players in the programmes, aspiration by beneficiaries for higher education and abolition and/or abatement of obnoxious cultural practices take place as envisaged by programme planners. The attendant impact level indicators are district wide level high literacy and numeracy rates and increased number of (female) graduates. 


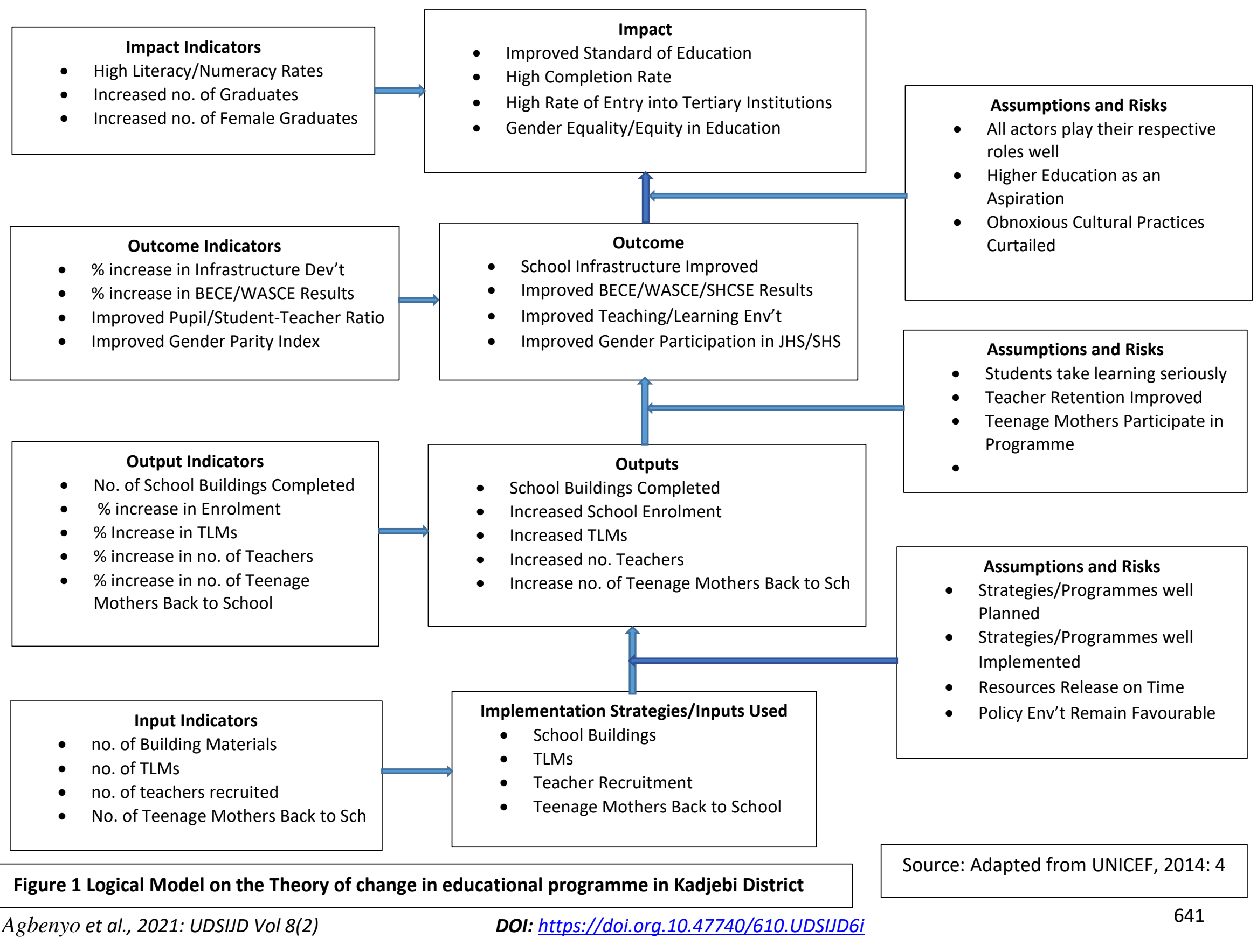




\section{Conceptual Framework}

Figure 2 is the conceptual framework guiding analysis of gender and education in societal development in the paper. The framework portrays a hypothesis that when external agents and agencies come into a society with their development interventions (education participation programmes, projects, plans, strategies), depending upon the nature of the societally assigned roles, expectations, support systems and benefit sharing modalities for both males and females, that society can either develop or become worse off. The top-most rectangle represents the external organisations including non-governmental organisations, bilateral/multilateral organisations, faith-based organisations, political organisations, professional bodies and private sector.

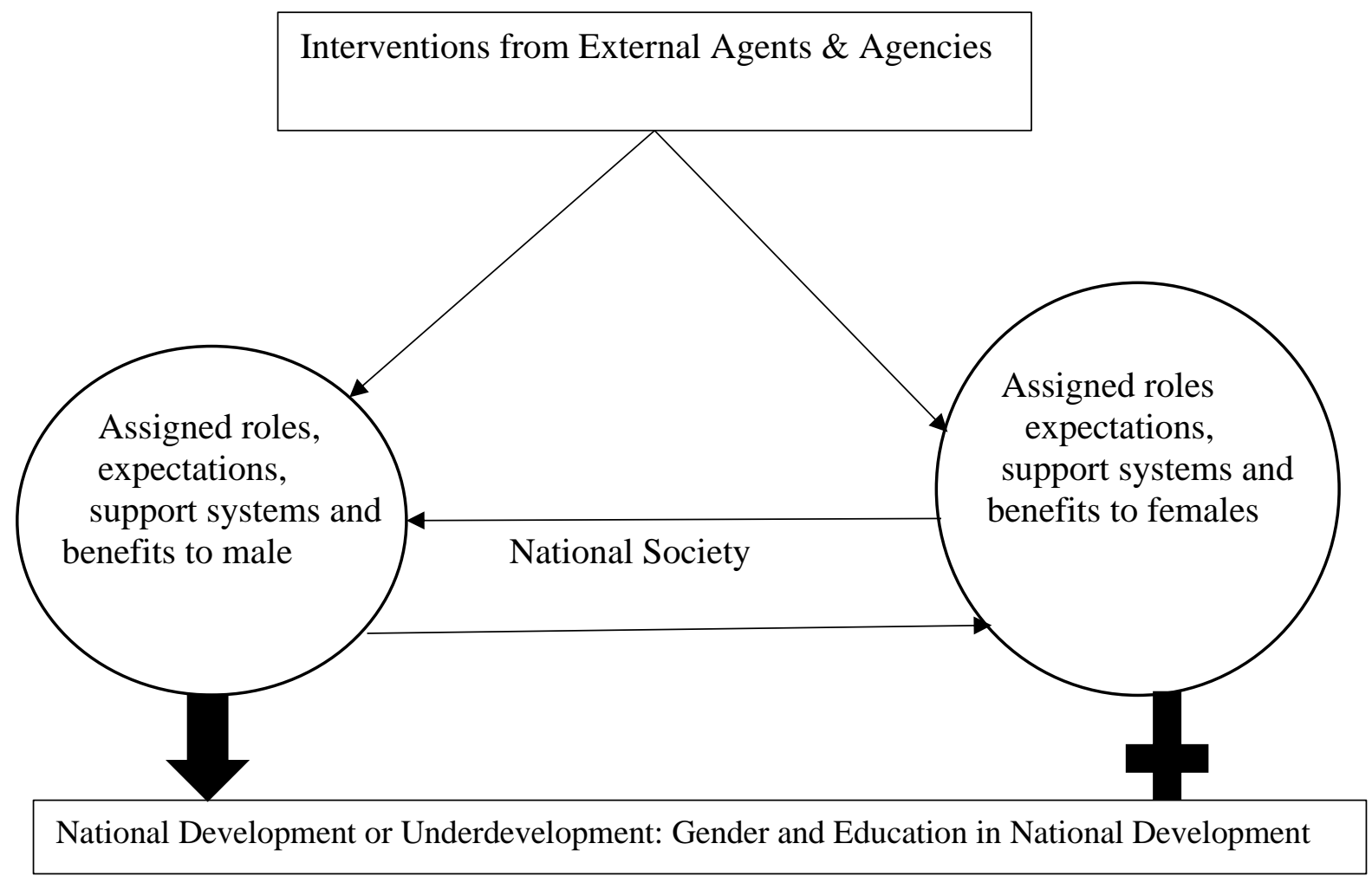

Figure 2. A Conceptual Framework on Gender Participation in Education in Ghana

Source: Authors' Construct, August 2019 with ideas from Agbenyo (2019); Muddiman (1999a; 1999b); Duffy (1995); Slavin (2010); Chapman (2006); De la Brière \& Rawlings (2006)

The two opposite diagonal arrows to the immediate circles below the top rectangle represent the education participation interventions, which these external agents and agencies bring into the society with gender perspective. The two circles, one with an arrow down and the other with a plus sign symbolize males and females respectively. These signs indicate that gender roles, expectations, support systems and benefit sharing can either take their roots from biogenic or sociogenic sources. Those that take their roots from biogenic sources cannot be ceded off without negative consequences 
while sociogenic ones can be deconstructed and reconstructed. In-between the two sexes/genders, lies the society which assigns the social roles to the two sexes. This is where the debate ensues as to whether these assignments by the "society" are really biogenic when they are expected to be biogenic and sociogenic when they are expected to be sociogenic. It is argued in the literature that there are biases in these assignments that have led to gender discrimination in various societies with different shades, dimensions and extents (see Blackstone, 2003).

The rectangle at the bottom of the framework represents national development, narrowly defined as growth and qualitative improvements in education spurred by appropriately, unbiasedly, equally and/or equitably assigned societal roles, expectations, support systems and benefit sharing modalities. What emanates from the relationships become national underdevelopment when there are inappropriately, biasedly, unequally and/or inequitably assigned societal roles, expectations, support systems and benefit sharing modalities.

\section{Gender and Education in Ghana: Some Empirical Considerations}

The period 2008-2012 witnessed a four percent (4\%) more enrollment for girls in pre-school than boys. Parity was almost achieved between boys and girls in terms of net enrollment and attendance ratios for primary school; while net enrollment stood at about $84 \%$ for both sexes, net attendance was about $73 \%$ for both. The lag in enrollment into secondary schools for girls was quite low as compared to that of the boys though undesirably low for both sexes; they stood at $44.4 \%$ and $48.1 \%$ respectively. However, girls' attendance was higher, $43.6 \%$, than that of boys $39.7 \%$ (see UNICEF, 2014). Lewin (2011) noted that at the national level, about $40 \%$ of six-year-olds are not in school; a figure that has reduced to about $10 \%$ for the 11-year-old age group. He emphasized that children above age 11 who have not yet enrolled are not likely to ever enroll. Trading Economics and World Bank (2020) have also reported that in 2019, the net enrolment rate (NER) for females at the primary school level in Ghana stood at $87.17 \%$, which was higher than that of their male counterparts, which stood at $86.25 \%$, giving a net enrolment gender parity index of 1.0108 while the total NER stood at $86.7 \%$ for both sexes. The lower secondary (Junior High School) level NERs also show same tendency with the females standing at $50.89 \%$, the males standing at $47.49 \%$ yielding a net enrolment gender parity index of 1.0715 and a total net enrolment rate of $49.15 \%$. The tendency is not different at the upper secondary (Senior High School) level where the females' NER stood at $34.99 \%$, the males' stood at 34.38 with a NER gender parity index of 1.0179 and a total NER of $34.68 \%$.

Packer et al. (2010, cited in Camfed 2012) indicated that certain factors influence education of girls either positively or negatively. These include recruitment, training, placement and attendance of teachers. The authors placed basic education absenteeism rate at $27 \%$. This is against the fact that Government of Ghana spent $25 \%$ of national budget annually on teacher remuneration. Again, a factor to discuss in this section is budgetary allocation to the sector to prosecute various interventions in relation to girls' education. According to Bruns et al. (2003), high level of political commitment which finds expression in budgetary allocations are very key to the success of programmes targeted at education of girls. Other factors outlined by Allsop et al. include livelihoods/careers and wider policies concerning gender, corporal punishment, child labour and donor partnership harmonization. Packer et al. (2010) have also noted that lack of female teachers, limited number of girls' schools, some cultural barriers, safety and security, irrelevant curricula and rigid educational systems that do not take on board girls' peculiar needs contribute negatively to girls' education. Lewin (2011) also added the need for managed expansion of the secondary sector; the need for a focus on 'the margins' - in terms of geographic and social locations; a focus on over-age enrolment; better monitoring systems for pupils and teachers to the list. 
According to Mahama and Nkegbe (2017), gender inequality in school enrollments still remain a major concern in Ghana today. The authors argue that in the face of having to send multiple children to school, economic and cultural norms serve as factors that influence decisions of school attendance between a son and a daughter. They found that there is persistence of a cultural belief that the major role of women and girls in society is reproduction. Others have argued that because reproduction is the major function of women and girls, parents who struggle to educate their girl-children are faced with two devils; either the girl will not get a husband to marry or another man who will be the husband, will be the beneficiary of investments which the parents have made in her. In the face of these inhibitions, boys have become the preferred option to be sent to school with the assumption that they will necessarily be the breadwinners for their families. According to Mahama and Nkegbe (2017), in urban schools in Ghana on the average, the ratio is two boys for every one girl and that in both rural and urban settings, the preference is on boys for enrollment over their girl counterpart.

\section{Methodology}

The paper employed purely quantitative data applied to a case study research design for gender and educational study in the Kadjebi District. Kadjebi, one of the six (6) districts in the newly created Oti Region, carved out of the then Volta Region, has been randomly selected from the six (6) districts declared as deprived in terms of educational development since 2013. The District falls within an underdeveloped enclave that forms the basis for the creation of new regions in Ghana in 2018/2019. The other districts are Nkwanta North and South, Krachi East and West, and Nchumuru. The District lies between Lat. $0^{\circ} \mathrm{S}$ and $30^{\circ} \mathrm{S}$ and Long. $8^{\circ} \mathrm{W}$ and $30^{\circ} \mathrm{W}$ (Republic of Ghana, 2019). It is bordered to the north by the Nkwanta South, to the south by the Jasikan and to the west by Biakoye Districts, and to the east by the Republic of Togo with a total land area of $949 \mathrm{~km}^{2}$. The District has a 2019 projected total population of 61,520 , made up of 31,623 (51.4\%) females and 29,867 (48.6\%) males, giving a sex ratio of 106 (i.e. 106 females per 100 males). In terms of distribution of educational institutions, the District has 91 kindergartens and primary schools, made up of 71 public and 20 private ones. Currently, there are 59 Junior High Schools (JHSs) (47 public and 12 private) and three senior high schools (SHSs), two public and one private (Republic of Ghana, 2019).

The paper relied on secondary source and type of educational data from annual census figures from the Kadjebi District Education Directorate. The use of the quantitative data from the secondary source was mainly because the education directorate is the repository of all comprehensive educational data in the District including those needed to achieve the objectives of the paper. Again, the quantitative data provide empirically measurable indicators that can be used to assess the performance of the educational sector in the District. The case study was adopted in the manuscript because, as stated under the study location, Kadjebi is just one of the six districts declared as deprived in terms of education in the then Volta Region. Kadjebi was selected as a case because authors are interested in the performance of the educational sector in the District. These secondary data were collected using data extraction sheets in July 2020 with MS Excel as the main analytical software.

The formulae for the analysis were derived from the UNESCO-UIS (2020), where the indicators and variables with their computational procures have been displayed. The paper relied on the UNESCO-UIS formulae because they properly fit the data set used in this manuscript and are well standardized.

For purposes of this paper, the emphasis was placed on gross enrolment rates looking at the total for the Lower Secondary (Junior High) school level $\left(\mathrm{GER}_{(\mathrm{JT})}\right)$, females for the Junior High school level $\left(\mathrm{GER}_{(\mathrm{JF})}\right)$ and males for the same level $\left(\mathrm{GER}_{(\mathrm{JM})}\right)$ including the gender parity rate $\left(\mathrm{GPI}_{(\mathrm{J})}\right)$ and for the Upper Secondary (Senior High) School level $\left(\left(\operatorname{GER}_{(\mathrm{ST})}\right)\right.$, females for the Senior High School level $\left(\mathrm{GER}_{(\mathrm{SF})}\right)$, males for the same level $\left(\mathrm{GER}_{(\mathrm{SM})}\right)$ plus the gender parity index $\left(\mathrm{GPI}_{(\mathrm{S})}\right)$. 
$\mathrm{GER}_{(\mathrm{JT})}$ is the total number of students of the official Lower Secondary (Junior) School age group who are enrolled in the Lower Secondary (Junior High) school or higher expressed as a percentage of the corresponding population. Its computational formula is given as:

$$
\begin{aligned}
& \mathrm{GER}_{(J T)}= \begin{array}{c}
\text { Total number of students in the of ficial junior High school age range } \\
\text { enrolled in Junior High Education or higher }
\end{array} \\
& G E R_{(J F)}= \frac{\begin{array}{c}
\text { Total number of femalation of the same age group } \\
\text { age group enrolled in Junior High School or higher }
\end{array}}{\text { Corresponding female popuation }} \\
& G E R_{(J M)}= \frac{\text { Total number of male students of the of ficial Junior Secondary School }}{\text { age group enrolled in Junior Secondary or higher }} \\
& \text { Corresponding male popuation }
\end{aligned}
$$

$\mathrm{GPI}_{(\mathrm{J})}$ is the ratio of female gross enrolment rate for Junior High School to the male gross enrolment rate for Junior High School. See the formula below:

$G P I_{(J)}=\frac{\operatorname{GER}_{(J F)}}{\operatorname{GER}_{(J M)}}$

GPI = 1 implies parity between males and females. A GPI value less than 1 indicates parity in favour of males and a value greater than 1 indicates a disparity in favour of females.

$\mathrm{GER}_{(\mathrm{ST})}$ is the total number of students of the official Upper Secondary (Senior High) School age group who are enrolled in Upper Secondary (Senior High) School or above expressed as a percentage of the corresponding population. The formula is stated as:

$$
G E R_{S T}=\frac{\begin{array}{c}
\text { Total number of students of the of ficial Senior High School group } \\
\text { enrolled in Senior High School or higher }
\end{array}}{\text { Population of the same age group }} \times 100
$$

$\mathrm{GER}_{(\mathrm{SF})}$ is also the total number of female students of the official Upper Secondary (Senior High) School age group enrolled in Upper Secondary (Senior High) School or higher, expressed as a percentage of the corresponding female population. The formula is:

$$
G E R_{S F}=\frac{\begin{array}{l}
\text { Total number of female students of the of ficial Senior High School group } \\
\text { enrolled in Senior High School or higher }
\end{array}}{\text { Population of the corresponding age group }} \times 100
$$

$\mathrm{GER}_{(\mathrm{SM})}$ is the total number of male students of the official Upper Secondary (Senior High) School age group enrolled in Senior High School or higher, expressed as a percentage of the corresponding female population. It is computationally determined as:

$$
G E R_{S M}=\frac{\begin{array}{c}
\text { Total number of male students of the of ficial Senior High School group } \\
\text { enrolled in Senior High School or higher }
\end{array}}{\text { Population of the corresponding age group }} \times 100
$$

$\mathrm{GPI}_{(\mathrm{S})}$ is the ratio of female gross enrolment rate for Senior High School to the male gross enrolment rate for Senior High School. See its computational formula below:

$G P I_{(S)}=\frac{\operatorname{GER}_{(S F)}}{\operatorname{GER}_{(S M)}}$ 
The interpretation is as in (4) above.

The data was presented in tables and charts, discussions made and conclusions drawn from them.

\section{Results and Discussions}

\section{Gender and Education in Kadjebi District}

The results have been organized and discussed according to the relativities between males and females at the JHS and SHS levels in the District. Specifically, it looks at gender based gross enrolment rates for both basic and second cycle levels, gender parity on gross enrolment rates for both the basic and second cycle levels, completion rates by gender at both levels, pass rates at both levels and quality indicators at both levels by gender.

\section{Gross Enrolment Rate (GER) by Gender for the JHS}

As presented in Figure 3 and supported by Figure 1, the Gross Enrolment Rate GER) by gender for the JHS paints a very good picture. Between the year 2014/2015 and 2018/2019, the least GER stood at 88\%, for females and $90 \%$ for males, which both occurred in 2015/2016 academic year. The highest for females stood at $101.3 \%$ while that of males was $103.1 \%$. The highest total GER was 100 percent while the lowest was $89 \%$ which were obtained in the 2014/2015 and 2015/2016 academic years respectively.

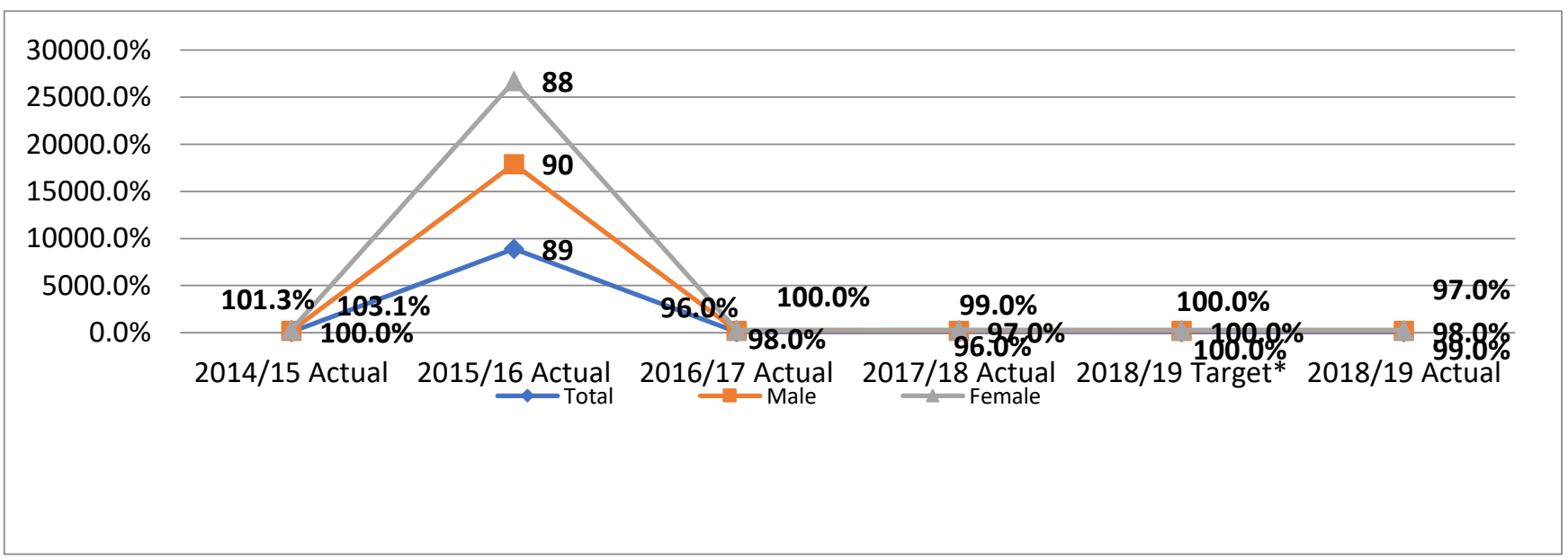

Figure 3: JHS Gross Enrolment Rate (GER) by Gender

Source: Kadjebi District Education Directorate (KDED), 2019

It is worthy of notice that the difference between the lowest GER for males and females, both of which occurred in 2015/2016 was only $1 \%$ while that of the highest GER was only $2.2 \%$, which occurred in 2014/2015 academic year, showing very close gaps. The Net Enrolment Rate (NER), which is on the main data base shows similar close disparities between 2014/2015 and 2018/2019 academic years. Generally, it can be observed that the figures plummeted from highs in the 2014/2015 academic year to the lowest in 2015/2016 when the World Bank programme was winding up. It gradually picked up in the 2016/2017 academic year and peaked in 2018/2019 for the total and male enrolments but with the females still lagging behind that of the previous year with 2 percentage points. These results can be described as good strides towards achievement of the SDG 4, particularly, when the District missed the MDG 2 target in the 2015/2016 academic year. The performance of this indicator under the various interventions, reflects the proposition by Cameron (2006) that social inclusion is a policy intervention issue which sees to the betterment of the lots of the vulnerable in society. 


\section{Gender Parity Index (GPI) on Gross Enrollment Rate at the JHS Level}

The close gender disparities within the period under consideration as shown in Figure 3 are reflective in the Gender Parity Index (GPI) on GER shown in Figure 4, with the least being 0.91 in 2015/2016 and the highest being 0.99 each which occurred in 2016/2017 and 2018/2019 respectively. What is striking about the GPI in the District is that as opposed to the planners' projected figure of 1.00 in $2018 / 2019$, which is the perfect parity between boys and girls, the figure shot up only by 0.01 to end at 0.99 (see also Figure 1).

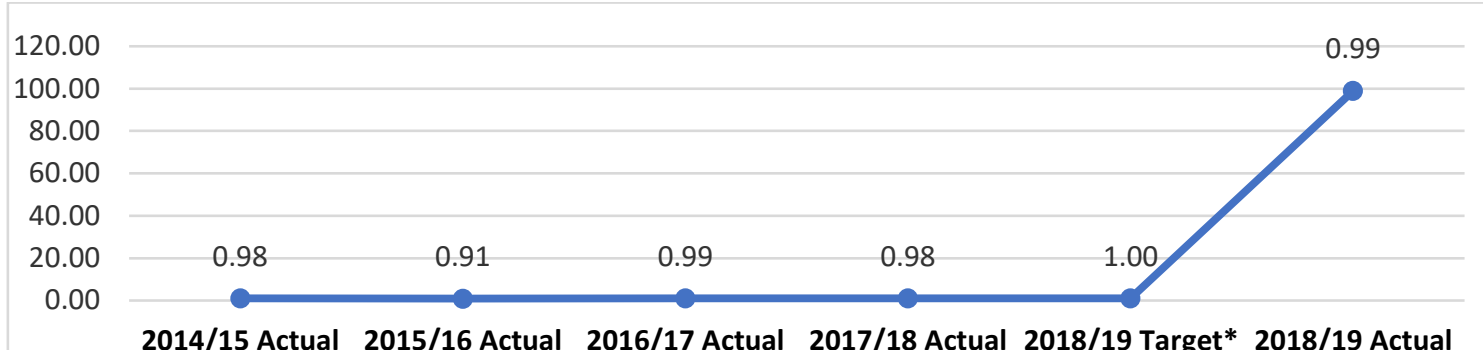

Figure 4: JHS Gender Parity Index (GPI) on GER

Source: Kadjebi District Education Directorate (KDED), 2019

The direction of this indicator implies that in 2015/2016 the District experienced gender disparity in favour of the boys to the slight disadvantage of the girls; that is, more boys have still been enrolled at the JHS level than their girl counterparts. In order words, from 2014/2015 to 2018/2019, the girls were still the disadvantaged group in terms of participation in JHS education. Measuring these indicators against the UN cut-off point of between 0.97 and 1.03 as indicative of acceptable gender parity (UNESCO-UIS, 2018: 33), the District can be adjudged as performing very well under the implemented interventions. As depicted in Figure 2, the conceptual framework, these results also imply that the sociocultural factors including the societal assignment of roles based on the sexes in the District, might have been working in tandem with others that influence this indicator of the programme interventions. However, the 2015/2016 figure of 0.91 is an unacceptable gender parity against the girls in favour of the boys. Clearly, the District has now achieved this indicator of the SDG 4 in good time, though the opposite was the situation under the MDG 2. It can be inferred here, also, that gender participation in education which the theory of inclusion emphasized is at play in the District as the various interventions have begun to produce their results (Slavin, 2010; Chapman, 2006; De la Brière \& Rawlings, 2006).

\section{Completion Rate (CR) at JHS 3 by Gender}

The next indicator that is very crucial under the SDG 4 is the Completion Rate at JHS 3 by gender. As in the case of GER and GPI, the lowest CR occurred in 2015/2016 with the value standing at $43.6 \%$, for the total average completion rate (TCR), that of males standing at $49.1 \%$ and the females' standing at 37\% (Figure 5). Even though these CRs are very low and can be described as unacceptable, the gender disparity, which is 0.75 , can even be said to be worse against the girls. However, as results of the intervention progressed, the trend showed a reversal. The highest occurred in 2018/2019 with TCR of 93\%, that of males being $90 \%$ and females also being 96\%, with gender disparity of 1.06 which is over and above the acceptable range in favour of the girls. In 2016/2017, 2017/2018 and 2018/2019, CR by gender actually favoured the females. 
Even though there is room for improvement both in terms of the TCR and the gender aspect, the results are encouraging; however, this can only be described as a partial achievement of target 4.1 under indicator 4.1.1, which goes beyond completion rates and operationalises quality, a more structural indicator, as minimum levels of proficiency in reading and numeracy also by sex (UNESCO Institute for Statistics [UIS], 2018; Figure 1).

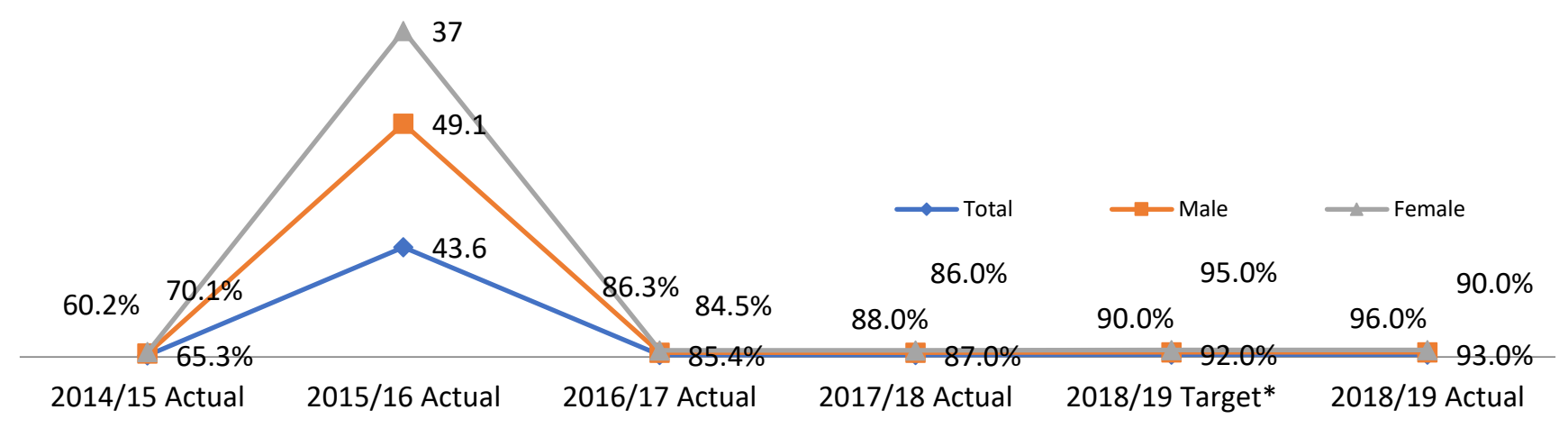

Figure 5: Completion Rate at JHS by Gender

Source: Kadjebi District Education Directorate (KDED), 2019

To be targeted and catered for by external agents for purposes of completion of education at this level is a key feature of inclusivity as captured under the SDG 4 (see also UNESCAP, 2015; UNDP, n.d.).

\section{BECE Pass Rates at the District Level}

The BECE pass rates at the district level depicted in Figure 6 are generally very low. The pass rate is a more structural indicator than just the enrolment, gender parity and completion rates because it changes more gradually and requires more efforts and inputs of intervention. It ranges between the lowest total pass rate of $31.4 \%$ and that of boys of $30.2 \%$ (both in 2014/2015) and 20\% in 2017/2018 for the girls. The highest total pass rate of $43 \%$ occurred in 2018/2019, that of boys of 56\% was recorded in the 2017/2018 academic year while that of girls of $47.60 \%$ was recorded in $2015 / 2016$. The differences are not alarming, even though more actions need to be taken to further reduce the difference in the pass rate between boys and girls in the District. What stands out about these pass rate figures is that in the 2015/2016 academic year, when the World Bank/BOG programme was winding up, the girls' pass rate was higher than that of the boys by $17.30 \%$. This is heart-warming in that it shows clearly that with appropriate interventions, girls can also do better than their boy counterparts. These results are at the heart of social inclusion as a theoretical lens contextualized in indicator 4.1.1 under target 4.1 of SDG 4 and also featured in the TOC under Figure 1 (see UIS, 2018; Cameron, 2006). 


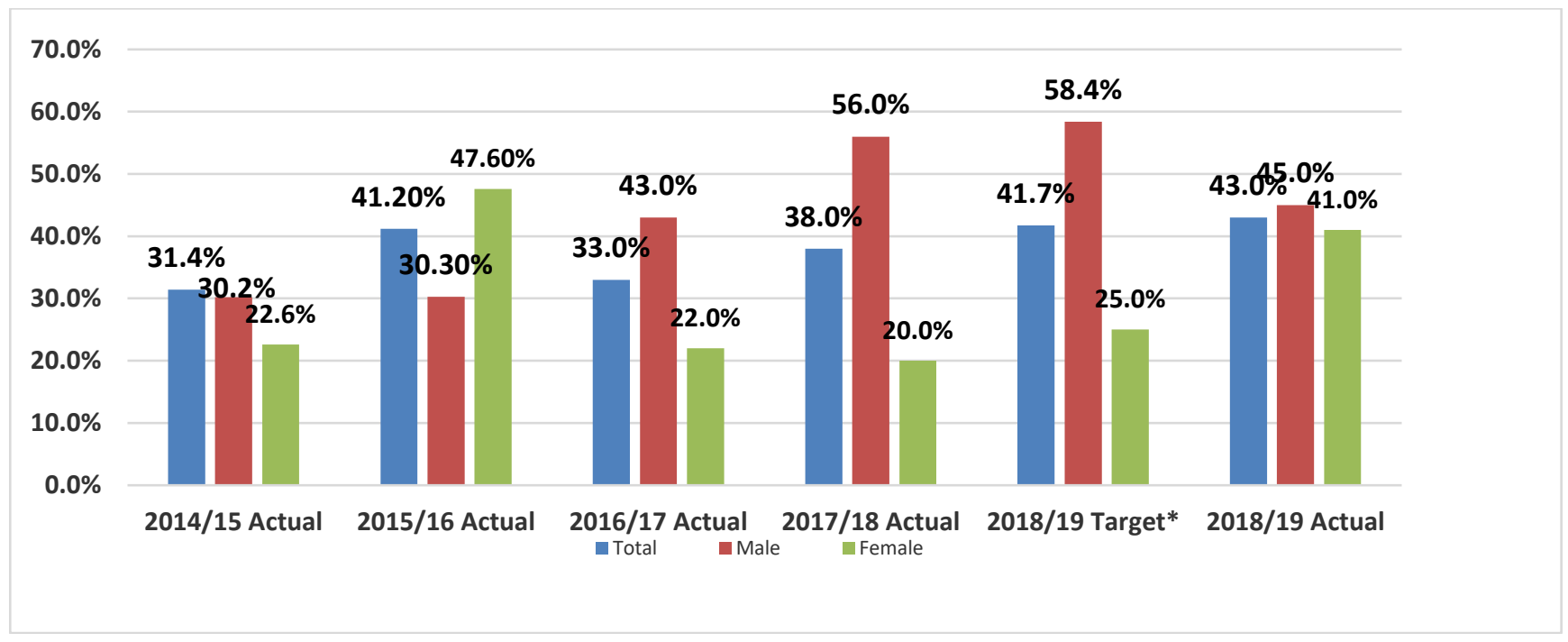

Figure 6: BECE Pass Rate by Gender

Source: Kadjebi District Education Directorate (KDED), 2019

\section{Quality Indicators at the Junior High School Level by Gender}

In Table 1, quality education indicators have been displayed (see also TOC under Figure 1). The percentage of female teachers in the District ranges from 2.5\%, the lowest to 25\%, the highest. In terms of disparities, these can be said to be very high and unacceptable when measured against target 4.c.1 and 4.c.2 of the SDG 4 (UIS, 2018). Since girls' education is receiving the needed attention in the District, there is the need for more female teachers to serve as their role models. The drop in percentage of female teachers from 16.1 in $2017 / 2018$ to 2.5 in $2018 / 2019$ as against the planners' projected figure of $25 \%$ increase is a pointer to the need to probe and ascertain the underlining causes for them to be addressed.

Table 1 Quality Indicators at the Junior High School Level by Gender

\begin{tabular}{|l|l|l|l|l|l|l|l|}
\hline \multirow{2}{*}{$\begin{array}{l}\text { Junior High School } \\
\text { Quality }\end{array}$} & \multicolumn{6}{|c|}{ District } \\
\cline { 2 - 8 } & $\begin{array}{l}2014 / 15 \\
\text { Actual }\end{array}$ & $\begin{array}{l}2015 / 16 \\
\text { Actual }\end{array}$ & $\begin{array}{l}2016 / 17 \\
\text { Actual }\end{array}$ & $\begin{array}{l}2017 / 18 \\
\text { Actual }\end{array}$ & $\begin{array}{l}2018 / 19 \\
\text { Target* }\end{array}$ & $\begin{array}{l}2018 / 19 \\
\text { Actual }\end{array}$ \\
\hline \multirow{2}{*}{$\begin{array}{l}\text { Number of } \\
\text { teachers in } \\
\text { all schools }\end{array}$} & Total & 274 & 254 & 333 & 403 & 406 & 438 \\
\cline { 2 - 8 } & Male & 236 & 210 & 281 & 338 & 334 & 351 \\
\hline $\begin{array}{l}\text { Percentage of female } \\
\text { teachers }\end{array}$ & 38 & 44 & 52 & 65 & 72 & 87 \\
\hline
\end{tabular}

Source: Kadjebi District Education Directorate (KDED), 2019

\section{Gender Parity Index (GPI) on Gross Enrollment Rate (GER) at the SHS level}

The GPI on GER at the SHS level has also shown tremendous improvements as portrayed in Table 2 and Figure 7 which also featured in the TOC in Figure 1. The lowest recorded within the District was unacceptably low at 0.58 in 2015/2016, which has improved to a high of 0.98 in 2018/2019, beating the statistician's projected figure of 0.80 by a clear 0.18 . Even though the parity index is high at the SHS level in the 2018/2019 academic year, it is far below that of the JHS which stands at 99.0, indicating that the interventions are yielding far better results at the basic level than the SHS level. According to the SDG 4 targets, gender parity is expected to be achieved in 2030; so, if in 2018/2019 the figure oscillates to 0.98 , it can be said that the District is doing well in this regard. 


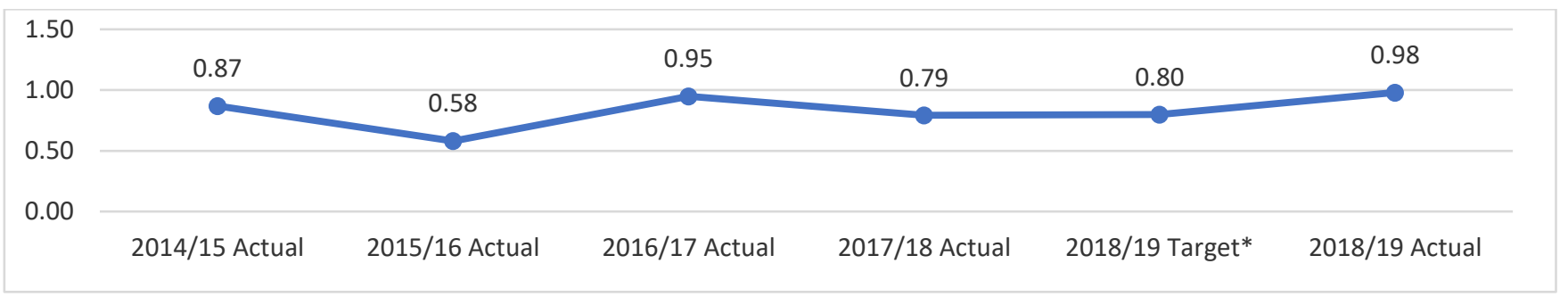

Figure 7: Gender Parity Index (GPI) on GER in SHS

Source: Kadjebi District Education Directorate (KDED), 2019

\section{Indicators of Access to Education by Gender at the SHS Level}

At the SHS level, it is obvious that lots of gains have been made judging from the indicators of access to education presented in Table 2 and Figure 1. The lowest Completion Rate of girls stood as high as 89\% while that of their male counterparts stood at $90 \%$, all in 2017/2018 and the highest for females being $96 \%$ $(2018 / 2019)$ while that of the males was recorded in 2014/2015 which stood at $99 \%$. It is interesting to note that looking at the trends, statisticians projected that girls' CR will be higher than that of the boys in 2018/2019 by $1 \%$ even though the reverse was what was recorded.

From Table 2, the trend of the GPI indicates that even though the District is moving towards a parity at the SHS level (0.98 in 2018/2019 from 0.58 in 2015/2016), its gender participation in education still favours the males as compared to the females.

Table 2 Access to Education Indicators by Gender at the SHS Level

\begin{tabular}{|l|l|l|l|l|l|l|l|}
\hline \multirow{2}{*}{ Senior High School } & \multicolumn{6}{|c|}{ District } \\
\cline { 3 - 9 } \multicolumn{2}{|c|}{} & $\begin{array}{l}2014 / 15 \\
\text { Actual }\end{array}$ & $\begin{array}{l}2015 / 16 \\
\text { Actual }\end{array}$ & $\begin{array}{l}2016 / 17 \\
\text { Actual }\end{array}$ & $\begin{array}{l}2017 / 18 \\
\text { Actual }\end{array}$ & $\begin{array}{l}2018 / 19 \\
\text { Target* }\end{array}$ & $\begin{array}{l}2018 / 19 \\
\text { Actual }\end{array}$ \\
\hline $\begin{array}{l}\text { Number of students in } \\
\text { all schools (Public \& } \\
\text { Private) }\end{array}$ & Total & 2,978 & 2672 & 3,138 & 2,956 & 3,061 & 3,278 \\
\cline { 2 - 8 } & Male & 1,825 & 1603 & 1,865 & 1,752 & 1,807 & 1,762 \\
\cline { 2 - 8 } & Female & 1,153 & 1069 & 1,273 & 1,204 & 1,254 & 1,516 \\
\hline $\begin{array}{l}\text { Gross Enrolment Rate } \\
(\text { GER })\end{array}$ & Total & $90.5 \%$ & 75 & $92.0 \%$ & $80.0 \%$ & $66.8 \%$ & $99.0 \%$ \\
\hline & Male & $94.3 \%$ & 91.8 & $94.3 \%$ & $73.1 \%$ & $73.7 \%$ & $98.0 \%$ \\
\cline { 2 - 9 } & Female & $82.5 \%$ & 76.8 & $89.5 \%$ & $57.9 \%$ & $58.9 \%$ & $96.0 \%$ \\
\hline $\begin{array}{l}\text { Gender Parity Index } \\
(\text { GPI) on GER }\end{array}$ & & 0.87 & 0.58 & 0.95 & 0.79 & 0.80 & 0.98 \\
\hline $\begin{array}{l}\text { Completion Rate at } \\
\text { SHS3 }\end{array}$ & Total & $96 \%$ & 96.8 & $94 \%$ & $96 \%$ & $98 \%$ & $97 \%$ \\
\cline { 2 - 8 } & Male & $99 \%$ & 98.5 & $98 \%$ & $90 \%$ & $97 \%$ & $98 \%$ \\
\cline { 2 - 8 } & Female & $93 \%$ & 95.1 & $92 \%$ & $89 \%$ & $98 \%$ & $96 \%$ \\
\hline
\end{tabular}

Source: Kadjebi District Education Directorate (KDED), 2019

Completion Rate by gender at the SHS level

The Completion Rate by gender at the SHS level is another useful SDG 4 indicator of how well a district is performing in terms of gender participation in education (see also Figure 1). In Figure 8, CRs of both males and females are very 
high with a lowest of $89 \%$ and the highest of $96 \%$ for the females in 2017/2018 and 2018/2019 respectively. In the case of the males, the lowest, $90 \%$, was recorded in 2016/2017 while the highest, $99 \%$, was also recorded in 2014/2015. Similar to the situation under the CR at JHS, it was projected in 2018/2019 that the female CR at SHS 3 will be higher than the males by $1 \%$. However, in the actual, that of the males was higher by $2 \%$. As compared to the CR at the JHS level where in $2015 / 2016$ females recorded as low as 37 and the males as low as 49.1 giving a total of 43.6 , values that are unacceptable, the CRs at the SHS level are generally high with a low of $90 \%$ and $89 \%$ for the males and females respectively and a high of $98 \%$ and $96 \%$ for males and females respectively. These high rates are partly explainable by the fact that students at the SHS level have left their parents and are under stricter school administrative control on their campuses. It is also a clear indication that interventions underway in the District at the SHS level are yielding the desired results, thus, helping to achieve target 4.1 of the SDG 4 (UIS, 2018).

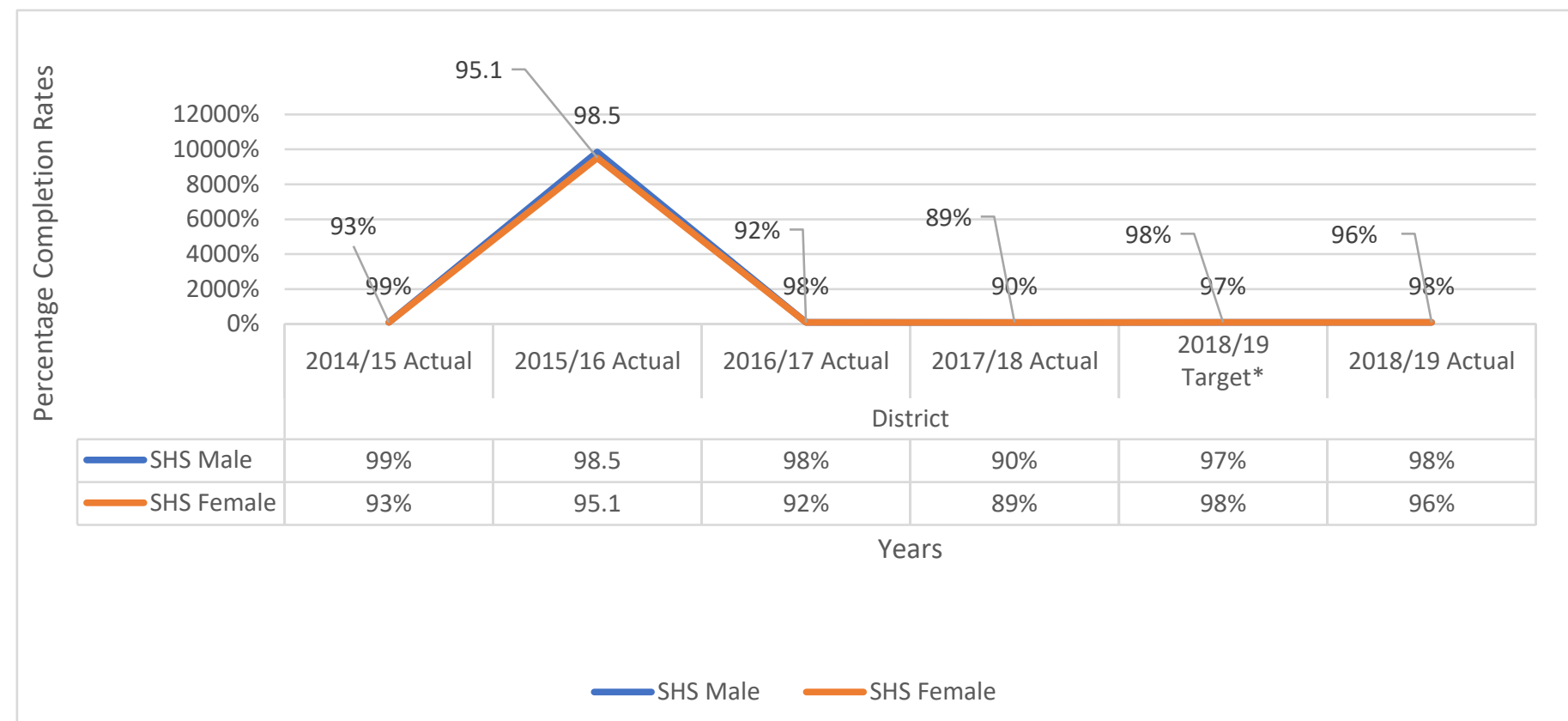

Figure 8: SHS Completion Rates by Gender

Source: Kadjebi District Education Directorate (KDED), 2019

\section{WASSCE Pass Rate at the SHS Level}

As in the case of pass rates at the JHS level, Figure 9 shows (see also Figure 1), clearly, that WASSCE pass rates in the District are unacceptably low. It ranges from $28.5 \%$ to $45 \%$ for the females in $2017 / 2018$ and $2018 / 2019$ and from $38.7 \%$ to $55 \%$ in $2017 / 2018$ and 2016/2017 respectively for males. If even under external programme interventions, pass rates are as low as indicated by the data, then it calls for concerted efforts at diagnosis of the specific inhibiting factors that are accounting for this level of learning outcomes. 


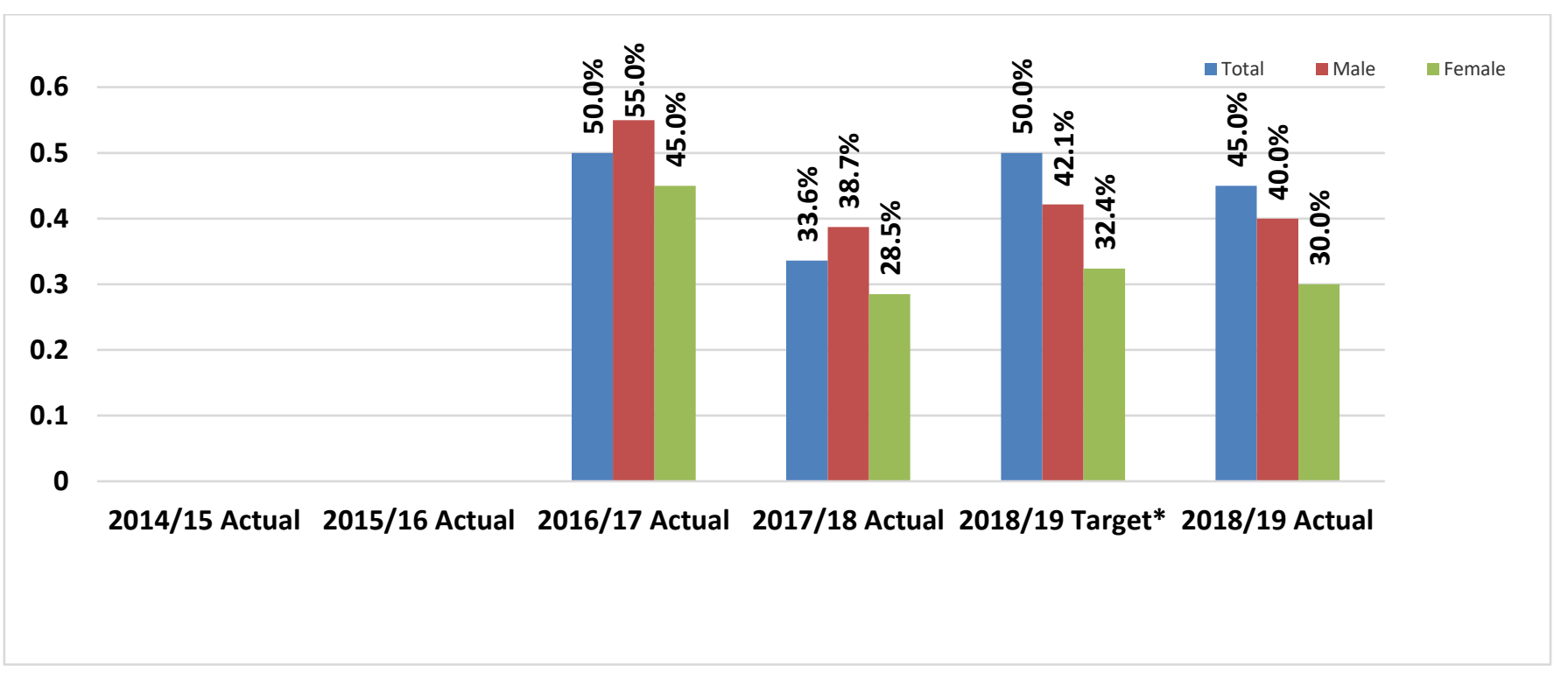

Figure 9: WASSE Pass Rate by Gender

Source: Kadjebi District Education Directorate (KDED), 2019

\section{Conclusion}

The intricacies involved in the gender participation in education discussed in this paper reflect the two pronged-hypotheses stated under the conceptual framework of the paper. All the indicators of gender participation in education in terms of access are pointing in the positive direction according to the goals and objectives of the intervention being implemented by external agents and agencies and in line with SDG 4. These indicators include Gross Enrolment Rates by gender, Net Enrolment Rates by gender, Gender Parity Index, Completion Rates by gender and Pass Rates at SHS by gender. These indicate that socially-assigned roles, expectations, support systems and benefit sharing modalities between boys and girls have responded positively to the goals and objectives of these interventions from external agents. On the other hand, indicators of educational quality, in the form of gender split of teachers at both levels of education show poor performances. This implies that socially-assigned roles, expectations, support systems and benefit sharing modalities between men and women have either been slow or non-responsive to the goals and objectives of interventions which are producing these undesirable results. It can be inferred that the barriers that inhibit female participation in quality education are imbedded in these socially-assigned roles, expectations, support systems and benefit sharing modalities between the two sexes.

It is, therefore prescribed that the Kadjebi District Assembly in collaboration with the Kadjebi District Education Directorate together with the other stakeholders in the education intervention programmes within the District undertake reviews of all the programmes that are underway with the view to diagnosing the contributory factors to the poor performance of the quality indicators of education in the District. This is also to afford the stakeholders the opportunity to coordinate their activities within the District, first for sustainability of their programmes and successes they have chalked and secondly to ensure that they are able to achieve the desired pass rates and subsequent transition into the next levels of education. This way, the theory of inclusion which found expression in SDG 4 would be seen to be in operation in the District.

\section{References}

Agbenyo, F. (2019). Factors influencing Parental choice of centre-based provision for early childhood care and education in 
Ghana. In Hasina Banu Ebrahim, Auma Okwany and Oumar Barry (Eds.). Early Childhood Care and Education at the Margins: African Perspectives on Birth to Three. New York; Routledge, Taylor \& Francis Group. Pp. 133 - 146.

Ansah, H. K. (2011). Impact of the Pilot Programmatic Scheme (PPS) on deprived districts: A comparison of well-endowed and deprived districts in education delivery in Ghana. MBA Dissertation, Wisconsin International University College, Accra, Ghana.

African Confidential (1989). Ghana. Florida; A Woman's Place.

Ameyibor, F. (2019).

Agenda 2030: Women in power and decisi on-making. Available at:

http://www.ghana.gov.gh/index.php/mediacenter/features/1331-agenda-2030women-in-power-and-decision-making. Accessed: 28/08/2019.

Archibald, T., Sharrock, G., Buckley, J. \& Cook, N. (2016). Assumptions, conjectures, an other miracles: The application of evaluative thinking to theory of change models in community development. Evaluation and Program Planning. Elsevier Ltd.

doi:10.1016/j.evalprogplan.2016.05.015

Blackstone, A. (2003). Gender Roles and Society. In Julia R. Miller, Richard M. Lerner, and Lawrence B. Schiamberg (Eds.). Human Ecology: An Encyclopedia of Children, Families, Communities, and Environments (Pp 335-338). Santa Barbara; ABC-CLIO.

Boateng, J. K. and Ansah, H. K. (2014). A Comparison of "Well Endowed" and "Deprived" Districts in Education Delivery in Ghana. Journal of Education and Practice 5(20); pp. 165-176.

Bruns, B., Mingat, A. \& Rakotomalala, R. (2003). Achieving universal primary education by 2015: A chance for every child. The World Bank. doi:10.1596/0-8213-5345-4.
Burchardt, T., Le Grand, J. \& Piachaud, C., 2002, 'Degrees of exclusion: Developing a dynamic, multidimensional measure', In J. Hills, J. Le Grand \& D. Piachaud (Eds.). Understanding Social Exclusion. Oxford: Oxford University Press.

Cameron, C. (2006). Geographies of welfare and exclusion: Social Inclusion and Exception. Progress in Human Geography, 30 (3), 396-404.

Camfed, Ghana (2012). What Works in Girls' Education in Ghana: A critical review of the Ghanaian and international literature. Camfed, Ghana, for the Ministry of Education and the Girls' Education Unit, Ghana Education Service, with support from DFID, Ghana.

Chapman, K. (2006). Social transfers and equitable access to education and health services. Background Papers Scaling up Services Team. DFID Policy Division. January, 2006. Available at: http://www.dfid.gov.uk/pubs/files/socialtra nsfers-back.pdf.

CIA Factbook (n.d.). Africa: Ghana. The CIA World Factbook. The Central Intelligence Agency. https://www.cia.gov/the-worldfactbook/countries/ghana/. Accessed: 27/08/2019.

Cornnell, J.P. \& Klen, A. M. (2000). You can get there from here: Using a theory of change approach to plan urban education reforms. Journal of Education and Psychology Consultation. 11 (1), 93 - 120.

De la Brière, B. \& Rawlings, L. B. (2006). Examining conditional cash transfer programs: A role for increased social inclusion? World Bank: Social Protection Discussion Paper no. 0603, June 2006.

Duffy, K., 1995, Social Exclusion and Human Dignity in Europe. Strasbourg: Council of Europe." before "Food and Agriculture Organisation of United Nations (2020).

Department of Social Development (2012). South African Social Security Agency and United Nations Children's Fund, The South 
African Child Support Grant Impact

Assessment: Evidence from a survey of

children, adolescents and their

households. UNICEF South Africa,

Pretoria, 2012, p. 6. Available @

http://www.unicef.org/southafrica/SAF

resources_csg2012s.pdf.

Food and Agriculture Organisation of the United

Nations (2020). Sustainable Development

Goals. FAO. Available at:

http://www.fao.org/sustainable-

development-goals/mdg/goal-2/en/.

Accessed 23/06/2020.

Gertler, P.T., Martinez, S., Premand, P., Rawlings, L. B. \& Vermeersch, C.M. J. (2016). Impact evaluation in practice $\left(2^{\mathrm{nd}}\right.$ ed.). International Bank for Reconstruction and Development/World Bank.

Gertler, P.T., Martinez, S., Premand, P., Rawlings, L. B. \& Vermeersch, C.M. J. (2011). Impact evaluation in practice. International Bank for Reconstruction and Development/World Bank.

Government of Ghana (2003). The Education strategic plan (2003-2015): Policies, targets and strategies. Vol. 1. Accra; Ministry of Education.

Government of Ghana (2012). The Education strategic plan (2010-2020): Policies, strategies delivery and finance. Vol. 1. Accra; Ministry of Education.

Lewin, K. (2011). Expanding access to secondary education: Can India catch up? International Journal of Educational Development, 31 (4), 382-393.

Mahama, T. A-K. \& Nkegbe, P. K. (2017). Gender Preference in Primary School Enrolment among Households in Northern Region, Ghana. Ghana Journal of Development Studies. 14 (1), 60-78.

March, C., Smyth, I. \& Mukhopadhy, M. (1999 reprinted in 2005). A Guide to GenderAnalysis Frameworks. Oxfam GB.

Muddiman, D. (1999a). Public libraries and social exclusion: the historical legacy. Leeds: School of Information Management, Leeds
Metropolitan University (Public Library Policy and Social Exclusion Working Papers no.1).

Muddiman, D. (1999b). Theories of social exclusion and the public library. Leeds: School of Information Management, Leeds Metropolitan University (Public Library Policy and Social Exclusion Working Papers no.2). 1"

National Council on Women and Development, Ghana (1989 - 1990). Conference papers, proceedings and periodicals. Available at: http://worldcat.org/identities/lccnn79060861/. Accessed: 28/08/2019.

Owusu-Ansah, D. (1994). The Position of Women. In (La Verle Berry). A Country Study: Ghana. Library of Congress Federal Research Division (November 1994). Available at: https://cdn.loc.gov/master/frd/frdcstdy/gh/ ghanacountrystud00berr0/ghanacountry stud00berr0djvu.txt. Accessed: 28/08/2019.

Packer, Allsop, Dvorak, Stanley, \& Wirak (2010). Afghanistan Education Analysis. Adam Smith International. Available @ http://www.giz.de/en/downloads/en-adamsmith-international- draft-nespassessment-2011.pdf.

Rawal, N. (2008). Social inclusion and exclusion: A review. Dhaulagiri Journal of Sociology and Anthropology, 2, 161-180.

Republic of Ghana (1992). The 1992 Constitution of Ghana. Accra; Parliament of Ghana.

Republic of Ghana (2019). Annual District Performance Report: Kadjebi Education Directorate.

Rogers, P. (2014). Theory of Change. Methodological Briefs: Impact Evaluation 2, UNICEF Office of Research, Florence.

Slavin, R. E. (2010). 'Can financial incentives enhance educational outcomes? Evidence from international experiments.

Educational Research Review, 5(1), 6880. Available @ https://www.sciencedirect.com/science/arti 
cle/abs/pii/S1747938X09000499.

Accessed: 26/08/2019.

UNESCO Institute of Statistics [UNESCO-UIS] (2020). Data for Sustainable Development Goals: SDG 4 data explorer. Available at: http//:uis.unesco.org/. Accessed: 15/10/2020.

United Nations Development Programme (n.d.). Sustainable Development Goals 2030. UNDP.

United Nations Development Programme (2016). Women in politics pledge to bridge inequality gap on Ghana's political landscape. Available at: https://reliefweb.int/report/ghana/ womenpolitics-pledge-bridge-gender-inequalitygap-ghana-s-political-landscape. Accessed: 26/08/2019.

United Nations Economic and Social Commission for Asia and the Pacific (2015). Statistical Yearbook for Asia and the Pacific 2015: Sustainable Development Goal 4 Equality Education. UNESCAP.

United Nations Educational, Scientific and Cultural Organisation Institute for Statistics (2018). Quick guide to education indicators for Sustainable Development Goal 4. New York; UNESCO-UIS.

United Nations Educational, Scientific and Cultural Organisation (2017). Unpacking Sustainable Development Goal 4 Education 2030: a guide. New York; UNESCO.

United Nations International Children's Fund (2014). Supplementary programme note on theory of change. New York; UNICEF.

UNFPA-UNICEF (2013). Joint Programme On Female Genital Mutilation/Cutting: Accelerating Change 2008 - 2012 Final Report - Volume 1. New York; UNFPAUNICEF. Available @UNFPA_UNICEF \%20Evaluation \%20of\%20FGMreport\%2012_4_2013.pdf.

White, H. (2009). Theory-based impact evaluation: Principles and practices.
International Initiative for Impact Evaluation.

Yusif, H., Yussof, I. and Osman, Z. (2013). Public university entry in Ghana: Is it equitable? International Review of Education / InternationaleZeitschrift für Erziehungswissenschaft / Revue Internationale de l'Education.59(1):727. JSTOR $\underline{42636125}$. 